\title{
Perceptions and feelings about physical changes in climacteric women
}

\section{How to cite this article:} Curta JC, Weissheimer AM. Perceptions and feelings about physical changes in climacteric women. Rev Gaúcha Enferm. 2020;41(esp):e20190198. doi: https://doi.org/10.1590/19831447.2020.20190198

\footnotetext{
Grupo Hospitalar Conceição (GHC), Residência Multiprofissional com Ênfase em Saúde da Família e Comunidade. Porto Alegre, Rio Grande do Sul, Brasil. Universidade Federal do Rio Grande do Sul (UFRGS), Escola de Enfermagem, Departamento de Enfermagem Materno-Infantil. Porto Alegre, Rio Grande do Sul, Brasil.
}

\section{ABSTRACT}

Objective: To know the perceptions and feelings about the physical changes of climacteric women in a city of Rio Grande do Sul. Method: Qualitative exploratory descriptive study developed with 16 women on public spaces of Porto Alegre/RS/Brazil, in September and October of 2018; data gathered through semi-structured interviews and submitted to thematic analysis.

Results: Four themes were found:" "Knowledge (or not) on climacteric and menopause (and their differences)","Changes perceived", "Changes felt", and "How to deal with climacteric and menopause".

Conclusion: Women have little information on climacteric; it is the nurses'responsibility to clarify about these phases, offer emotional support and indicate physical activities that may ease their signs and symptoms.

Keywords: Nursing. Climacteric. Menopause. Women's health.

\section{RESUMO}

Objetivo: Conhecer as percepp̧̧es e sentimentos sobre as alteraç̧ões corporais de mulheres climatéricas em uma cidade do Rio Grande do Sul.

Método: pesquisa qualitativa exploratório-descritiva realizada com 16 mulheres, em setembro e outubro de 2018, em espaços públicos de Porto Alegre/RS, por meio de entrevistas semiestruturadas e cujas informaçōes passaram por análise temática.

Resultados: Foram obtidos quatro temas: "Conhecimento (ou não) sobre o climatério e a menopausa (e suas diferenç̧as)","Alterações percebidas", "Alteraç̄ôes sentidas" e"Como lidar com o climatério e a menopausa".

Conclusão: As mulheres têm poucas informaç̃oes sobre o climatério; à enfermeira cabe esclarecer sobre suas fases, oferecer suporte emocional e indicar atividades físicas que podem amenizar seus sinais e sintomas.

Palavras-chave: Enfermagem. Climatério. Menopause. Saúde da mulher.

\section{RESUMEN}

Objetivo: Conocer las percepciones y sentimientos acerca de las alteraciones corporales de mujeres climatéricas en una ciudad de Rio Grande do Sul.

Método: Investigación cualitativa exploratoria-descriptiva realizada con 16 mujeres en espacios públicos de Porto Alegre/RS/Brasil, en septiembre y octubre de 2018, a través de entrevistas semiestructuradas y cuyas informaciones pasaron por análisis temático. Resultados: Se han obtenido cuatro temas: "Conocimiento (o no) sobre el climaterio y la menopausia (y sus diferencias)," "Alteraciones observadas", "Cambios sentidos"y "Cómo lidiar con el climaterio y la menopausia".

Conclusión: Las mujeres poseen poca información sobre el climaterio; es responsabilidad de la enfermera aclarar sobre los pasos, ofrecer ayuda emocional e indicar actividades físicas que pueden aligerar sus señales y síntomas.

Palabras clave: Enfermería. Climaterio. Menopausia. Salud de la mujer 


\section{口INTRODUCTION}

Puberty is seen as a natural part of a woman's life, a stage marked by the menarche, in which physical changes such as hormonal and emotional ones take place. The climacteric should also be treated as a natural phase, having the menopause as its main event

The climacteric, according to the World Health Organization (WHO), is defined as a biological phase of life and not as a pathological process. It includes the transition between the reproductive and non-reproductive periods of a woman, in other words, between menacme and elderliness, and is determined by the drop in production of estrogen and progesterone hormones by the ovaries. Menopause, a landmark of this phase, corresponds to the last menstrual cycle that is only recognized after twelve months after its occurrence and usually happens between ages 48 and $50^{\text {(1) }}$.

The Health Ministry establishes ages between 40 and 65 years as a limit for the climacteric, divided in: premenopausal - that starts mostly after age 40 , with a descent of progesterone levels, lowering of fertility in women that still have regular menstrual cycles or with menstrual patterns similar to what was expected during reproductive life; perimenopausal - starts two years before the last menstrual cycle and lasts up to one year after it (with irregular menstrual periods and endocrine alterations); and postmenopausal - begins one year after the last menstrual cycle $e^{(1-2)}$.

During the climacteric period, about 60 to $80 \%$ of women experience some kind of symptomatology, mostly due to the state of hypoestrogenism which occurs after the recession of the ovary function. The most frequent signs and symptoms are menstrual irregularity, the appearance or worsening state of premenstrual tension and menstrual colic, palpitations, dizziness, tiredness, memory shortening, headache, joint pain, anxiety, irritability, insomnia, depression, dyspareunia, micturition urgency, vaginal dryness, and heat waves ${ }^{(3)}$. It is important to emphasize that the complaints that interfere the most in the quality of life of women are from a psychosocial and affective nature, such as sorrow, discouragement, tiredness, lack of energy, depressing mood, anxiety, irritability, insomnia, attention, concentration and memory deficit, grief and diminished sex drive ${ }^{(4)}$.

Although women in this stage experience many climacteric symptoms, they do not know or cannot identify most hormonal, physiological and emotional changes involved in the processes of hormonal production decrease and menstrual cycle end. It is important to preserve the well-being and quality of life during the entire female vital cycle, but considering the increasing number of climacteric women, provoked by the changes in the demographic profile caused by higher life expectancies in Brazil and in the population of the world, there is a scarcity of public policies for women's health in this stage, coupled with a lack of knowledge about the many morbidities that can affect these women ${ }^{(5)}$.

Brazilian life expectancy increased drastically from 1940 to 2015: longevity at birth, for both genders, has gone from 45.5 to 75.5 years of age, a 30-year increase. There is also a striking difference among genders, with an expectancy of 71.9 years for men and 79.1 for women ${ }^{(4)}$. Today, women are a majority within the Brazilian population;25,977,502 of them are from 40 to 65 years old, according to 2010 census from IBGE ${ }^{(6)}$. Consequently, they are the main users of the Unified Health System (SUS), making this a relevant subject regarding public health.

The climacteric induces a woman to reflect about her life trajectory. It is a stage that coincides with a series of events such as retirement, siblings leaving home, and health issues that come with age ${ }^{(7)}$. However, it affects each one in a different manner, having repercussions in their feelings and quality of life; it is important that they feel good about themselves and try to balance their frustrations and victories ${ }^{(8)}$.

As a result of the affirmatives above, the guiding question of this study emerged: "What do women understand about the climacteric, and how do they feel and notice the physical manifestations that come from it?" - which has led to the purpose of knowing the perceptions and feelings about body changes of climacteric women in a city from Rio Grande do Sul.

\section{METHOD}

This is a qualitative study with an exploratory and descriptive nature, which is indicated when there is a need to explore a phenomenon, opinion, or perception ${ }^{(9)}$. It derives from the conclusion thesis of the nursing graduation course written by the main author.

The samples were collected in public areas such as parks, because it is believed that the Health Units are places that people seek in order to cure an illness. Therefore, instead of being places in which women could search for health promotion or disease prevention, they would use it for diseases treatments. At the parks, it was possible to encounter "ordinary" women who were going through the climacteric.

Thus, the population of the study included women going through the climacteric, of which 16 made up the sample of this study. The number of participants was defined based on the criteria of information saturation, in other words, collection stopped after answers were redundant and there was no new information ${ }^{(9)}$. Women between 40 and 65 years of age that were aware of the signs and symptoms of the 
climacteric were included in the study; the investigation excluded women that had had an early menopause (when the last period occurred before the predicted age, that is, before age 40), which can happen spontaneously, as a manifestation of an autoimmune disease, or be induced by pathologies, gene alterations, medications, irradiations, or surgery ${ }^{(10)}$. Since these women have not experienced the climacteric within the expected age group considered "normal", they end up not feeling the other issues inherent to age and aging.

The data collection took place within the months of September and October of 2018. It was done through a semi-structured interview, using an instrument that allowed to trace a brief profile of the women and that had open questions about the topic. Women were approached in public places of Porto Alegre by the researcher (an undergraduate Nursing student by the time), identified with the University badge. Initially, the physical aspect that would indicate the age group to which the subject belonged was taken into consideration, that is, the appearance of being over 40 years old. The subjects were addressed carefully as to avoid causing any type of embarrassment, such as treating them as "weathered" or "old". After the participant decided to accept the invitation to take part of the study and confirmed her age, she was presented with the Free and Informed Consent Form and signed it. Only then the interview would proceed in a venue of mutual consent, at the park itself, accounting for minimal conditions of comfort and privacy such as sitting on a bench, for example. The interviews were recorded by digital means and later transcribed by the researcher.

The thematic analysis, as defined by Minayo ${ }^{(11)}$, was used. It includes the steps of pre-analysis, material exploration, and obtained results treatment and interpretation.

The ethic precepts from CNS resolution 466/2012 $2^{(12)}$ were respected. The research project presented here was appreciated and approved by the Research Ethics Committee of the Universidade Federal do Rio Grande do Sul under CAAE 94124518.8 .00005347$.

\section{RESULTS AND DISCUSSION}

Chart1 presents the characteristics of the 16 women who composed the sample.

\begin{tabular}{|c|c|c|c|c|c|}
\hline Age & \multicolumn{3}{|c|}{47 to 65 years (average of 56.4 years) } & & \\
\hline \multirow{2}{*}{ Conjugal situation } & Married & Divorced & Widow & & \\
\hline & 12 & 03 & 01 & & \\
\hline \multirow{2}{*}{ Number of siblings } & None & One & Two & Three & Four \\
\hline & 03 & 05 & 06 & 01 & 01 \\
\hline \multirow{2}{*}{ Occupation } & Work & Retired/stay at I & & & \\
\hline & 09 & 07 & & & \\
\hline \multirow{2}{*}{ Physical activity } & Yes & No & & & \\
\hline & 10 & 06 & & & \\
\hline \multirow{2}{*}{ Sickness } & Yes & No & & & \\
\hline & 11 & 05 & & & \\
\hline \multirow{2}{*}{ Medication usage } & Yes & No & & & \\
\hline & 09 & 07 & & & \\
\hline
\end{tabular}

Chart 1 - Sample characterization Source: Research data, 2018. 
The physical activities were walking, Pilates, muscle training, dance, or aquarobics. The 11 women that declared having diseases informed having diabetes, hypertension, asthma, osteoporosis, or cardiovascular disease. They were not questioned as to what medication they made use of.

In search of an answer to the question of the study, it was possible to get to know, in addition, what kind of knowledge women had, or not, about climacteric and menopause, and even if there was or not a difference among these concepts in their perception. It was also possible to know how interviewed women handled the noticeable or felt changes in this period of life.

As a result, the interview analysis made it possible to bring forth four topics: "Knowledge (or lack thereof) about the climacteric and menopause (and their differences)", "Noticed changes","Felt changes", and "How to deal with the climacteric and menopause", which will be discussed below.

\section{Knowledge (or lack thereof) about the climacteric and menopause (and their differences)}

The climacteric represents the transition between the reproductive and non-reproductive stages of a woman's life. It is a physiological phenomenon resulting from the depletion of ovary follicles that occurs in every middle-aged woman, followed by a gradual drop of estradiol discharge, culminating with the definitive disruption of menstrual cycles (menopause) and the appearance of characteristic symptoms ${ }^{(13)}$.

Even though some women knew what climacteric was, their knowledge was noticed to be vague with regards to its definition, as evidenced below:

Climacteric is that pre-menopause period, that is neither one thing or the other. Like adolescence, you know? Stop menstruating, but once in a whileyou still have it. Months go by, nothing happens, and then it comes again. (M1)

\section{[...] it's when you stop having your period. (M2)}

Climacteric is that phase where you start to lose menstrual cycles, that comes before menopause, you have to have at least two years of period interruption to be able to say that it is menopause. That is the climacteric phase. (M5)

The climacteric? I have heard that word, I don't remember now, but I think it has something to do with hormones. Climacteric must be the temperature. (M6)
[...] it is the symptoms that you get before menopause.

That are hot flashes. (M7)

Climacteric to me is the woman's last period.(M8)

Aren't they the heat waves?(M10)

Well, I think climacteric is pre-menopause, or isn't it? But I think it is. Pre-menopause, it is a precedent to those symptoms that, you know, that you are out of the house and you don't know why, you don't understand what is happening to you. (M14)

Climacteric is the period when the symptoms that precede menopause appear. (M15)

Climacteric, if I'm not mistaken is the period which anticipates menopause. (M16)

It was noticed that they did not have a full grasp as to the meaning of this topic. The lack of knowledge about this step was noticeable due to the statements of the interviewed subjects, who often associated it with infertility:

I am not sure if the climacteric is post-stopping or if it is in the beginning, but I know it is something like that. (M12)

Climacteric is that woman's phase in which reproduction ends, right? It is the ending of your fertility. (M4)

About menopause, all interviewed subjects claimed to know what it means and it became clear that they have a higher knowledge of its definition. Most of them said it was when the menstrual periods cease, though there was still confusion about the symptoms.

It is when we stop having our periods. (M3)

Menopause is the ending of the menstrual cycle, right. (M4)

Menopause is the suspension of menstrual periods. (M6)

It is the ending of menstrual periods. During menopause I won't get pregnant anymore. (M7)

Menopause I know, they are heat waves that a person gets after their period stops. (M9) 
Menopause is when we stop getting our periods and then get hot flashes. (M10)

I think menopause is already the ending, when you go through a whole year without getting any period at all, menopause is defined. (M14)

Menopause is when the menstrual period stops and those awful hot flashes start and there is a hormonal reduction of hormones. (M16)

\section{Noticed changes}

Regarding noticed body changes, menstrual alterations were mentioned, as well as vasomotor symptoms, sleep disorders, neuropsychiatric symptoms, urogenital alterations and sexual dysfunctions, metabolic alterations, and skin diseases.

As the ovulatory dysfunctions start, the reproductive capacity diminishes, and consequently, the menstrual alterations also do ${ }^{(14)}$.

I saw that it started to gap, and then I noticed it was alternating. I would have it one month and then not the other. (M4)

...the menstrual period sometimes falters during the month... (M15)

The vasomotor symptoms were the most noticeable among the interviewed women, only three of them made no reference to them. The most prevailing symptom was heat waves, popularly known as "hot flashes", which constitutes the most common symptom in western women, which can be experienced during any stage of the climacteric, frequently accompanied by sweating. Its intensity may vary a lot, from mild to very intense ${ }^{(1)}$. Women described their experiences with hot flashes:

... you wake up in the middle of the night, you were sleeping and then "woosh", that heat, it started on the neck at first, then it started down and went up from my toes, and up, then it stopped, then you fall back to sleep... (M2)

... I only have it sometimes some hot flashes at night. I'd kick the covers. On, off, off, on. (M4)

... suddenly that heat came in my face, the back of my neck, I would get sweaty, sometimes during the winter I was home and had to take my sweater off. (M7)
I had a lot of hot flashes, it is something that starts heating up fast, comes to your head and you are dripping sweat and after it's gone, you get cold. (M8)

The main things that bring discomfort in the beginning are the hot flashes. (M11)

Sometimes I'm at the street or somewhere with a lot of people and then I get so hot, the face turns red and the hotness brings with it a sick feeling. And at night I have to keep taking the covers off and then the cold comes back. (M16)

Studies show that quality of sleep diminishes during the climacteric, which is often related to vasomotor symptoms ${ }^{(15)}$. This worsening is confirmed by the statement of some women:

... the insomnia, lack of sleep. Sleeping, waking. There was no deep sleep. (M2)

I noticed insomnia...(M8)

What caused me discomfort was [...] and insomnia. (M14)

The neuropsychiatric changes include emotional instability, anxiety, nervousness, irritability, struggle to make decisions, sadness, and depression, among others. These could be experienced separately or jointly in any period during the climacteric with variable intensity ${ }^{(1)}$. As an example:

I did get annoyed, I feel it, you know. Less tolerant with things. (M5)

I noticed irritability... (M8)

More forgetfulness... (M11)

... it was awful, an anxiety, a shortness of breath, I thought

I was going to die, choked. (M12)

... you get angry, ill tempered... (M14)

Among genital symptoms, the most frequent are those resulting from urogenital atrophy such as vaginal dryness, dyspareunia, and urinary urgency, with important repercussions on sexuality and quality of life, caused by reduced estrogen levels ${ }^{(16)}$. The statements below demonstrate how some participants felt these manifestations: 
Ah, one more thing. The lack of libido that comes with menopause. (M2)

... and not to say other things, vaginal dryness and vaginal atrophy are things that get in the way a lot. (M8)

... and sexual drive has diminished. (M12)

Among the main organic dysfunctions that may occur during the climacteric are changes in the bone metabolism, promoting the manifestation of osteoporosis; in the lipid metabolism, elevating the risk of cardiovascular diseases; and there is a replacement of muscle by fat tissue, which results in a higher tendency for weight gain ${ }^{(17)}$. The women noticed those changes, stating that:

Well, I think I am chubbier than I used to be. (M1)

... on the other hand there was a high loss of calcium in my body. (M7)

... weight loss became much harder and weight gain much easier. (M13)

... metabolism is slow... (M15)

... less muscle, more fat... (M11)

It is highly likely that the degree of thinning and loss of elasticity that happens on the aging skin is directly related to hypoestrogenism, given there are existent receptors to the hormone in the skin. Nails may look dry, with a fragile appearance, brittle and opaque. Hairs become thin and spaced $^{(14)}$. Women have felt those changes and expressed them as follows:

[l feel] more flaccid... (M2)

... the hair got thinner... (M8)

... the skin ages more... (M11)

... hair loss, weak fingernails... (M15)

\section{Felt changes}

The feelings seen in women related to climacteric were connected to the intensity of those noticed alterations and also with how the woman lives her life. Most women thought this phase was positive or indifferent and only five had negative feelings about the climacteric. First of all, some examples of those who considered the climacteric a good period of their lives:

Actually, menopause was the best thing that ever happened in my life. Nowadays I thank God, I had to use both a tampon and a pad to be able to spend three hours comfortably, today I don't have any of that, I don't have this worry, thank God it stopped. (M1)

... to me it was very good, I had no worries, had no stress, no problems, like, to have to do hormonal replacement. (M3)

I will say that I was happy as I could be because the work that was having a period and cramps was over. That part in my life has ended and I am loving it, I feel great. Felt no difference in my body. I feel really good. And on the contrary, I feel strong and whole. Not once has it taken away my sexual appetite, the lust. On the contrary, it has made me more sexually active and powerful. You don't worry, you don't need to be careful, you won't get pregnant. (M4)

... I felt I was getting to that phase, so lembraced it! (M5)

... stopped having my period, thank God. (M6)

On the other hand, those who experienced climacteric as a negative phase said:

I felt very bad, everything is bad, not one thing is good. I think it is horrible, I feel like it is an injustice to a woman. (M8)

Ifelt very bad, even to get out of the house it was bad. (M9)

We don'tfeel good, but know they are inevitable for those who get to this age. (M11)

Regarding my looks I felt bad, because I gained weight and lost a lot of hair. (M15)

It is important to emphasize that, in western cultures, regarding physical beauty; women are valued for their youth and maternity, whose loss may foster feelings of neglect, sorrow and even depression. The intensification of the symptoms resulting from hypoestrogenism, combined with common events in this stage, such as the growth of 
children, retirement, or death of the spouse, demand emotional adjustments and lifestyle changes that are many times difficult for women ${ }^{(18)}$.

\section{How to deal with climacteric and menopause}

The hormonal replacement therapy (HRT) is indicated to relieve vasomotor symptoms, genito-urinary atrophy, and prevention of osteoporosis ${ }^{(14)}$. It has been observed that women who made use of HRT had had positive results, as they state:

I used hormonal replacement. There was an improvement. (M2)

I went to the doctor and started to take hormonal replacement. If there was an improvement? Yes, the hot flashes stopped. (M7)

The reason why I started with HRT now at age 60 was because of my lower sex drive, ok? And it got a lot better with this medication, by the way. (M14)

Physical activity is a valuable therapeutic resource that should be more explored in the years of the climacteric. As to quality of life, in women that are physically active the climateric symptoms felt were significantly less severe, which supports the positive role of physical activity in the climacteric ${ }^{(19)}$.

Studies show that sedentary women have higher chances of feeling symptoms when compared to those who claim to do physical activities in a frequency higher than three times a week, which emphasizes the importance of adopting a regular exercise routine in the period after menopause $\mathrm{e}^{(20)}$.

I think it always is the exercise. The gym helps a lot. Blood flow. You feel strong, active. Energetic, you know? (M4)

With exercise it (the symptoms) started to go away, getting better, I associated it to that. (M5)

I did physical exercises, changed my diet a little... There was an anger improvement. (M8)

But I owe all of it (little discomfort) to physical activity because everyonel know that feels those things don't do anything, they are sedentary; and that is their mistake, at least that is what I think. (M14)
Yes, I joined the gym to burn the calories. There was (improvement), I have lost weight, but I go to the gym three times perweek. (M15)

Physical activity should be seen by climacteric women as a powerful ally, because it enhances bone mineral density, improves the lipid profile, diminishes body fat, besides regulating blood pressure. That contributes to a smaller incidence of bone and cardiovascular comorbidities. Not only that, it also improves women's body image, building up their self-esteem and, as a consequence, their will to be affective and sexually active ${ }^{(18)}$.

\section{FINAL CONSIDERATIONS}

Considering that the climacteric is a phase that represents around a third of a woman's life about which there is a great lack of knowledge, and that it can bring women many discomfort and unpleasant symptoms, women and health professionals need to understand this phase better, especially nursing professionals, who must be able to help women to experience and figure out this period.

The statements of the interviewed women have made possible to answer questions about the purpose of getting to know the perceptions and feelings about body changes of climacteric women in a city of Rio Grande do Sul. It was possible to identify that they do not have a lot of information or knowledge about the climacteric, which was identified by them as pre-menopause, post-menopause, or menopause itself. The interviews also made it possible to know what they felt, the complaints or benefits that came with the ending of their menstrual periods. It was also noticed that their individuality, in other words, their personality, contribute to how each woman goes through this phase, whether in a positive or negative way.

As for the changes during the climacteric, all women presented some kind of complaint, although some were more intense than others. Moreover, it has been noticed that it is a period that is lived differently among women. Some take it as a positive experience while others, as a negative one.

The main role of nursing should be to create a space in which climacteric women can express their feelings about the moment they are living, offering necessary emotional support and information about the changes that the female body is going through, as a way to prevent the unpleasant changes and negative implications for their health. A fundamental necessity in nursing should be to recommend 
physical activity, considering the interviewed women stated that it is a great ally, easing the symptoms and improving their quality of life.

In addition to opening a space to women that are in the climacteric, nursing professionals should associate all consultations made with women in age proximity to the climacteric, whether they are aimed at addressing hypertension, diabetes mellitus, or chronic pain. They need guidance about signs, symptoms, and the definition of the climacteric and menopause, so that they enter the climacteric more prepared.

The small number of publications by the Brazilian nursing scholars on the subject may be seen as limitation to this study, especially with regards to contemporary literature, which mostly regards the pathophysiological aspects of the climacteric and how to deal with them. There was an attempt to associate the results of this study with those of other national publications, due to their inherent cultural features. The socioeconomic class to which the participants belonged can also be considered as a bias of this study, since the public venues in which the women were approached are located in high middle-class neighborhoods in Porto Alegre.

There is also a need for new researches that associate an assessment of the quality of life of women with climacteric symptoms to what they perceive and feel, so that nursing professionals can offer early guidance on proper nursing care and how to face this stage of life, which is highly important, but little discussed among women, making it a smoother and more pleasant, "trauma-free" transition.

\section{Q REFERENCES}

1. Ministério da Saúde (BR). Secretaria de Atenção à Saúde. Departamento de Ações Programáticas Estratégicas. Manual de atenção à mulher no climatério/ menopausa. Brasília, DF; 2008 [cited 2018 Dec 05]. Available from: http:// bvsms.saude.gov.br/bvs/publicacoes/manual_atencao_mulher_climaterio. pdf

2. Sociedade Brasileira de Endocrinologia e Metabologia [Internet]. Rio de Janeiro: SBEM; c2009-2018 [citado 2018 dez 05]. 0 que é climatério?; [approx. 1 screen]. Available from: https://www.endocrino.org.br/0-que-e-climaterio/

3. Peixoto LN, Araujo MS, Egydio CA, Ribeiro FE, Fregonesi CEPT, Carmo EM. Perfil e intensidade de sintomas de mulheres no climatério avaliadas em unidades básicas de saúde de Presidente Prudente. Colloquium Vitae. 2015;7(1):85-3. doi: https://doi.org/10.5747/cv.2015.v07.n1

4. Ministério da Saúde (BR), Instituto Sírio-Libanês de Ensino e Pesquisa. Protocolos da atenção básica: saúde das mulheres. Brasília, DF: Ministério da Saúde; 2016 [cited 2018 Dec 05]. Available from: http://bvsms.saude.gov.br/ bvs/publicacoes/protocolos_atencao_basica_saude_mulheres.pdf
5. Valença CN, Germano RM. Concepções de mulheres sobre menopausa e climatério. Rev. Rene. 2010 [cited 2018 Dec 10];11(1):161-71. Available from: http://www.periodicos.ufc.br/rene/article/view/4498/3398

6. Instituto Brasileiro de Geografia e Estatística [Internet]. Agência de Notícias IBGE. Riode Janeiro:IBGE; (2017-2018 [cited2018Dec 10]. Em 2016, expectativadevida era de 75,8 anos [approx. 1 screen]. Available from: https://agenciadenoticias. ibge.gov.br/agencia-sala-de-imprensa/2013-agencia-de-noticias/ releases/18470-em-2016-expectativa-de-vida-era-de-75-8-anos

7. Zanotelli SS, Ressel LB, Borges ZN, Junges CF, Sanfelice C. Vivências de mulheres acerca do climatério em uma unidade de saúde da família. Rev Pesq Cuid Fundam. Online. 2012 [cited 2018 Dec 10];4(1):2800-11. Available from: http://www.seer.unirio.br/index.php/cuidadofundamental/article/view/ 1632/pdf_492

8. Santos LM, Eserian PV, Rachid LP, Cacciatore A, Bourget IMM, Rojas AC, et al. Síndrome do climatério e qualidade de vida: uma percepção das mulheres nessa fase da vida. Rev APS. 2007 [cited 2019 Mar 10];10(1):20-6. Available from: http://www.uff.br/nates/files/2009/12/Climaterio.pdf

9. Polit DF, Beck CT. Fundamentos de pesquisa em enfermagem: avaliação de evidências para a prática da enfermagem. 7. ed. Porto Alegre: Artmed; 2011.

10. Cavadas LF, Nunes A, Pinheiro M, Silva PT. Abordagem da menopausa nos cuidados de saúde primários. Acta Med Port. 2010 [cited 2019 Jan 10];23(2):227-36. Available from: https://www.actamedicaportuguesa.com/ revista/index.php/amp/article/view/612/296

11. Minayo MC. 0 desafio do conhecimento: pesquisa qualitativa em saúde. 11. ed. São Paulo: Hucitec; 2008.

12. Ministério da Saúde (BR), Conselho Nacional de Saúde. Resolução nº 466, de 12 de dezembro de 2012. Diretrizes e normas regulamentadoras de pesquisas envolvendo seres humanos. Diário Oficial da União. 2013 jun 13;150(112 Seção 1):59-62.

13. De Lorenzi DRS, Danelon C, Saciloto B, Júnior IP. Fatores indicadores da sintomatologia climatérica. Rev Bras Ginecol Obstet. 2005;27(1):12-9. doi: https://doi.org/10.1590/S0100-72032005000100004

14. Sociedade Brasileira de Climatério (BR). Consenso brasileiro multidisciplinar de assistência à saúde da mulher climatérica. São Paulo: SOBRAC; 2003.

15. Souza $C L$, Aldrighi JM, Lorenzi Filho G. Qualidade do sono em mulheres paulistanas no climatério. Rev Assoc Med Bras. 2005;51(3):170-6. doi: https:// doi.org/10.1590/S0104-42302005000300019

16. Leite MT, Taschetto A, Hildebrandt LM, Van der Sand ICP. 0 homem também fala: o climatério feminino na ótica masculina. REE. 2013;15(2):344-51. doi: https:// doi.org/10.5216/ree.v15i2.15424

17. Hoffmann M, Mendes KG, Canuto R, Garcez AS, Theodoro H, Rodrigues AD, et al. Padrões alimentares de mulheres no climatério em atendimento ambulatorial no Sul do Brasil. Ciênc Saúde Coletiva. 2015;20(5):1565-74. https://doi. org/10.1590/1413-81232015205.07942014

18. De Lorenzi DRS, Catan LB, Moreira K, Ártico GR. Assistência à mulher climatérica: novos paradigmas. Rev Bras Enferm. 2009;62(2):287-93. doi: https://doi. org/10.1590/S0034-71672009000200019

19. Tairova OS, De Lorenzi DRS. Influência do exercício físico na qualidade de vida de mulheres na pós-menopausa: um estudo caso-controle. Rev Bras Geriatr Gerontol. 2011;14(1):135-45. doi: https://doi.org/10.1590/ S1809-98232011000100014 
20. Silveira IL, Petronilo PA, Souza MO, Costa e Silva TDN, Duarte JMBP, Maranhão TMO. Prevalência de sintomas do climatério em mulheres dos meios rural e urbano no Rio Grande do Norte, Brasil. Rev Bras Ginecol Obstet. 2007;29(8):41522. doi: https://doi.org/10.1590/S0100-72032007000800006

- Corresponding author:

Julia Costa Curta

E-mail: juliacc0511@gmail.com

Associate editor:

Ana Karina Silva da Rocha Tanaka 